\title{
Editorial: Christine Petit-Jean-Genaz Receives the 2012 Robert H. Siemann Award
}

At the PRST-AB Editorial Board Meeting held during IPAC'12 in New Orleans, the 2012 Robert H. Siemann Award for outstanding contributions to the PRST-AB journal was bestowed upon Christine Petit-Jean-Genaz of CERN. Ms. Petit-Jean-Genaz serves as Executive Secretary and Treasurer of the EPS-AG, IPAC Coordinator for Europe, and JACoW Coordinator. The award citation emphasizes her initiation and promotion of PRST-AB Special Editions for several EPAC and IPAC conferences, and her encouragement of PRST-AB sponsorship by accelerator institutes in Europe and across the world.

The award, named after the PRST-AB founding editor, the late Robert H. Siemann, was established in 2012 by the editors of PRST-AB to recognize significant contributions to the journal. It consists of a PRST-AB pin and a certificate citing the contributions made by the recipient. The award is conferred during the annual PRST-AB Editorial Board meeting. The Robert H. Siemann Award shall ordinarily be given to one person, but may be shared when several recipients have contributed to the same accomplishment. Nomination proposals can be sent to the PRST-AB Editor, by any present or former PRST-AB Editorial Board member and PRST-AB Editorial Staff.

Frank Zimmermann

Editor

Published 17 May 2013

DOI: 10.1103/PhysRevSTAB.16.050001

PACS numbers: 01.10.Cr, 01.30.Ww

Published by the American Physical Society under the terms of the Creative Commons Attribution 3.0 License. Further distribution of this work must maintain attribution to the author(s) and the published article's title, journal citation, and DOI. 